\title{
THE ROLE \\ AND USE OF RELIGION IN THE POLITICS OF CANDIDATES TO THE POLISH THRONE IN THE $17^{\text {TH }}$ CENTURY*
}

A period of relentless and free election was required for the election of a suitable candidate for the throne of the former Polish-Lithuanian Commonwealth. Candidates to the throne attempted to obtain the support of the nobles, and, above all, influential magnates, in all possible ways. One of the most important aspects for voters was the religious tolerance of the future ruler. Each candidate for the Polish throne had to be a practising Catholic, but their attitude towards dissenters was also important, and religion was more than a bargaining unit during the competition for the throne of the Commonwealth. A separate issue, which is extremely interesting and important for the proposed deliberations, is the candidatures of dissenters whom the nobility wanted to see on the throne of the Polish-Lithuanian state. The purpose of this paper is to present the role played by religion, religious coercion, and the tolerance of candidates for the Polish throne, and how this aspect was used by them during electoral politics in the $17^{\text {th }}$ century ${ }^{1}$. Under this proposed angle, we shall therefore discuss five seven-

* The article was created as a result of historical research carried out under the Preludium 12 project entitled Attitudes of the elite of the Grand Duchy of Lithuania towards the election of Wladysław IV Vasa and Michal Korybut Wisniowiecki (Polish: Postawy elit Wielkiego Księstwa Litewskiego wobec elekcji Władysława IV Wazy i Michała Korybuta Wiśniowieckiego), project no. UMO-2016/23/N/HS3/00679, financed by the National Science Centre, Poland (Narodowe Centrum Nauki).

${ }^{1}$ It is worth emphasizing here that political and religious sphere in $17^{\text {th }}$ century Eu- 
teenth century elections: Władyslaw IV Vasa (1595-1648), Jan Kazimierz Vasa (1609-1672), Michał Korybut Wiśniowiecki (1640-1673), Jan III Sobieski (1629-1696), and August II Sas (1670-1733).

Since the beginning of the first interregnum in 1572, nobles and magnates had deliberated about how to choose the future ruler and on the person itself: what kind of personality traits should he possess, from what kind of background should he derive (should he be a Pole?), what faith should he believe in, should he be tolerant towards other religions or the reverse? Finally, during the interregnum after the death of Zygmunt August (1520-1572), it was assumed that the future king had signed two documents in which his obligations had been codified: the Henrykowskie Articles and pacta conventa. The first of these included provisions to guarantee religious freedom and tolerance. A separate document, which was to be accepted by every future ruler, was the Warsaw Confederation, guaranteeing equality between the nobility of every religion.

The first election, held within the chronological range under discussion, took place after death of Zygmunt III Vasa (1566-1632), on 30 April, 1632. There was basically only one candidate for the throne of the Polish-Lithuanian state, the eldest son of the deceased monarch, Prince Władysław Zygmunt. His younger brothers, Jan Kazimierz (1609-1672), Jan Albert (1612-1634), Karol Ferdynand (1613-1655) and Aleksander Karol (16141634), had withdrawn from the electoral struggle in full support of the aforementioned Vasa ${ }^{2}$. During this interregnum, the so-called 'Conspiracy of Orleans' (Polish: spisek orleański) certainly influenced the religious attitudes of the polish nobility. Allegedly, Gastón de Orleans (1608-1660), and even Bethlen Gábor (1580-1629), were supposed to be the next king after

rope were permeated. Heinz Schilling summarized this process as it follows: "Formed in the earliest years of the amalgamation of classical, Christian, and also Germanic elements, the profile of Europe, in terms of sociology of religion, was determined by the fact that religion and society, or rather the ecclesiastical and secular-political order, were - in contrast to the modern world of the nineteenth and twentieth century - not divided into separate spheres, but were structurally connected and functionally related"; H. Schilling, Confessionalization: Historical and Scholarly Perspectives of a Comparative and Interdisciplinary Paradigm, in: Confessionalization in Europe, 1555-1700: Essays in Honor and Memory of Bodo Nischan, ed. J. M. Headley, H. J. Hillerbrand, A. J. Papalas, (2004), pp. 21-35.

${ }^{2}$ W. Czapliński, Na dworze króla Władysława IV, (1959), p. 64; W. Kaczorowski, Sejmy konwokacyjny i elekcyjny w okresie bezkrólewia 1632 r., (1986), p. 40; T. Wasilewski, Ostatni Waza na polskim tronie, (1984) p. 10; A. Śliwiński, Król Władysław IV, (1924), p. 51. 
the death of Zygmunt III. Krzysztof Radziwiłł (1585-1640) was supposed to have been the instigator of the whole plot, which led to his falling into royal disgrace and a long-lasting conflict with the king. According to Henryk Wisner, Radziwiłł did not genuinely support Gastón in the fight for the throne. There were at least a few arguments for such a view, connecting the House of Radziwiłł with the Habsburg Monarchy and the religious intolerance of the Orleans candidate ${ }^{3}$.

The interregnum of 1632 was dominated by problems of religion and religious tolerance and, therefore, particularly intense activities were undertaken by the dissidents. There was some confusion in the policy of the Swedish king, Gustav II Adolf (1594-1632), who for some time, had been considering submitting his candidature to the Polish crown, but who ultimately withdrew. In spite of this, there were rumours of contacts made by Calvin and the Lithuanian field hetman, Krzysztof Radziwiłl, with Sweden, to fill the throne of the Commonwealth with the above-named king. Before the death of Zygmunt III, there had been secret meetings of senators in Lesser Poland (Małopolska) and Greater Poland (Wielkopolska) to create a common policy with regard to the future anticipated interregnum. During these meetings, however, their statements were not favourable towards the candidacy of Władysław Zygmunt, who was not considered to be a good and hard-working soldier. His belief in absolutum dominium was also stressed, as was his sickliness. As stated by Adam Szelągowski: "The dissident side had one more plea: horror sacrae missae, applicable to Władysław, and also any other Catholic pretending to the Polish crown" (in Polish: Dysydencka strona miała jeszcze jeden zarzut: horror sacrae missae, który się stosował również do Władysława, jak i do każdego innego katolika, który pretendował o tron w Polsce"). On the other hand, already during the interregnum, the Catholics had accused the prince of insufficient religious zeal. Some people even claimed that they would prefer to vote for the allegedly Protestant Gustav II Adolph than for Władysław Zygmunt,

${ }^{3}$ H. Wisner, Zygmunt III Waza, (2006), p. 209-210; W. Czapliński, Na dworze króla Władysława, pp. 51-52; A. Rachuba, Sapieha Kazimierz Leon, in: Polski Słownik Biograficzny, 35, 1 (1994), p. 31; J. Dorobisz, Biskup i książe. Jakub Zadzik i Krzysztof II Radziwiłł w elicie władzy pierwszych Wazów, in: Patron i dwór. Magnateria Rzeczypospolitej w XVI-XVIII wieku, eds. E. Dubas-Urwanowicz, J. Urwanowicz, (2006), pp. 353-354; more information about "spisek orleański": "Spisek orleański" w latach 1626-1628, ed. by U. Augustyniak, W. Sokołowski, (1990). 
who hid his atheism. Furthermore, the Holy See had some doubts about the piety of the prince, and the Pope's dissatisfaction had been aroused by his good contacts with the Protestant, Krzysztof Radziwiłł. It was in the interest of the Vatican, however, to support Władysław Zygmunt, who was popular with the nobility and had the best chance of gaining the Commonwealth throne ${ }^{4}$.

One can therefore argue that the dissidents sought, at least in the beginning of the interregnum, to crown the greatest protector of Protestantism in Europe - Gustav II Adolf. It should be noted, however, that the dissidents were aware of the popularity of Władysław Zygmunt among the nobles and would not dare to oppose him with a candidate who had no chance of winning. Besides, Krzysztof Radziwiłł, whose contacts with the Swedish king were not believed even by Vasa, nor probably by the rest of the dissenters, was aware that the prince, who was sympathetic towards their religion, had promised to mediate between the warring parties in the first months of the interregnum. The hypothetical candidacy of Gustav II Adolf could have appeared very frightening for Catholics. It could have led to the prolongation of the interregnum period (which was extremely dangerous because of the current threat from Moscow) or to trigger a civil war in the event of a split election. Both camps, Catholics and dissidents, feared Gustav II Adolf and the steps he could take after being chosen king. Therefore, the optimal and most appropriate choice for the conflicted parties was the Polish prince ${ }^{5}$.

Władysław Zygmunt had been raised in the Catholic faith but was supported by the nobility of every faith. One of the main instigators of his election was the above-mentioned Krzysztof Radziwiłł. On the other hand, there were zealous Catholics in his party, such as the relative to the aforementioned Chancellor, Albrycht Stanisław Radziwiłł (1593-1656). The Prince was known for his ambivalent approach to Catholicism and overall religious tolerance, in contrast to his father Zygmunt III, who favoured

4 A. Szelągowski, Układy królewicza Władysława i dysydentów z Gustawem Adolfem w r. 1632, in: Kwartalnik Historyczny, 13 (1899), pp. 683, 685, 701; W. Czapliński, Na dworze Władysława IV, (1959), pp. 64-65; W. Kaczorowski, Sejmy konwokacyjny i elekcyjny, pp. 40-41; Z. Anusik, Gustaw II Adolf, (1996), p. 205.

5 J. Dzięgielewski, O tolerancje dla zdominowanych. Polityka wyznaniowa Rzeczypospolitej w latach panowania Władysława IV, (1986), pp. 13-14; A. Szelągowski, Układy królewicza Władysława, pp. 696-697. 
Catholics, because, in the words of Jan Dzięgielewski, it was easier "for the implementation of the main objectives of the dynasty". As mentioned above, the convocation, and elective Sejm of 1632, were dominated by religious problems, and Władysław Zygmunt himself tried to mediate between the competing parties, thus elevating his authority in both the Catholic and the dissident camps. The nobles accepted his choice on 8 November, $1632^{6}$.

After the calm and consistent election of Władysław IV Vasa, the situation was different in the next interregnum in 1648. Two brothers of the king, sons of Zygmunt III Vasa - ex-Jesuit Jan Kazimierz and the bishop of Wrocław Karol Ferdynand - were candidates. The latter had a good chance of winning and was supported by the Emperor and Pope Innocent X. The election of Philip William of Neuburg (1615-1690) and the Elector of Brandenburg, Frederick William (1620-1688), were also considered ${ }^{7}$.

At the beginning of 1648, there was yet another suitable candidate. For some time, the protestant Prince of Transylvania, George I Rákóczi (1593-1648), was under consideration. After his death, his son Zygmunt (1622-1652), was also considered. The candidacy enjoyed strong support from Protestants, including Calvinists, Arians and Disunion (Polish: dyzunici). The Prince of Transylvania also counted on the help of: the Elector of Brandenburg, Wallachian Hospodar, Sweden, Turkey and Bohdan Chmielnicki (1595-1657). The candidacy of George I Rákóczi was also widely supported by the magnates and noblemen of Ukraine, headed by the Russian governor, Jeremi Wiśniowiecki (1612-1651). The proposals submitted by his deputies did not, however, meet with much support in Warsaw ${ }^{8}$.

During the Sejm, the candidate Bishop of Wrocław Karol Ferdynand, gained electoral advantage. The news of the death of George I Rákóczi came in October; therefore, his supporters, together with field hetman Janusz Radziwiłł (1615-1655), in fear of Karol Ferdinand standing aside, took the

${ }^{6}$ J. Dzięgielewski, O tolerancję dla zdominowanych, pp. 12-13; H. Wisner, Władysław IV Waza, (2002), pp. 57-59; W. Czapliński, Na dworze króla, pp. 66-67; S. Ochmann-Staniszewska, Dynastia Wazów w Polsce, (2006), p. 134.

7 Z. Wójcik, Jan Kazimierz Waza, (1997), pp. 44, 47.

8 A. A. Witusik, Sejm elekcyjny Jana Kazimierza, p. 134; M. Sawicki, Stronnictwo dworskie w Wielkim Księstwie Litewskim w latach 1648-1655, (2010), p. 106; Z. Wójcik, Jan Kazimierz Waza, pp. 46-47; W. Tomkiewicz, Jeremi Wiśniowiecki (1612-1651), (1933), p. 263. 
side of Jan Kazimierz. Under the influence of these events and the defeat at Piłowice, the rest of the supporters of Karol Ferdynand went to the side of the ex-Jesuit ${ }^{9}$. A meeting in Nieporęt on 1 November, 1648, was significant for the electoral struggle, where Janusz Radziwiłł negotiated the terms of support for the candidacy of Jan Kazimierz by Lithuanian dissidents ${ }^{10}$. This meeting was briefly summarized in the diary of Albrycht Stanisław Radziwiłł; "with Prince [Jan] Kazimierz was the hetman, the Samogitia foreman, and the Smoleńsk voivode, who came after him to Warsaw, had been invited to him and were recruited by him" (in Polish: "U królewicza [Jana] Kazimierza byli hetman, a zarazem starosta żmudzki, i wojewoda smoleński, którzy, zanim przybyli do Warszawy, zboczyli zaproszeni do niego i zostali przez niego pozyskani" ${ }^{11}$ ). Eventually, Jan Kazimierz, after gaining support from Bohdan Chmielnicki, was named King of the Polish-Lithuanian Commonwealth on 17 November, $1648^{12}$.

The abdication of Jan Kazimierz Vasa, in September 1668, aroused particularly high interest in the foreign states and the nobility itself. The most important candidates for the Polish-Lithuanian throne were: Charles of Lorraine (1643-1690), the Moscow Tsar, Aleksey Mikhailovich (1629-1676), and his sons Aleksey (1654-1670) and Feodor (1661-1682), Prince Louis de Burbon (le Grand Condé) and his son Henri (1643-1709), Philip William of Neuburg; and the 'Piasts'-Dymitr and Michał Wiśniowiecki, Aleksander Janusz Ostrogski Zasławski and the soldier Aleksander Polanowski ${ }^{13}$. It should be mentioned here that, during the electoral parliament in 1669, prohibitions were considered, in which the condition was made that only a Catholic could become the King of the Polish-Lithuanian Commonwealth (Rex catholicus esto). This excluded all representatives of other religions from political rivalry. This record was also confirmed in the pacta conventa of Michał Korybut Wiśniowiecki ${ }^{14}$.

9 A. A. Witusik, Sejm elekcyjny Jana Kazimierza, pp. 145-146; W. Tomkiewicz, Jeremi Wiśniowiecki, p. 264.

10 T. Wasilewski, Ostatni Waza, pp. 64-65; M. Sawicki, Stronnictwo dworskie, p. 116.

11 A. S. Radziwiłł, Pamiętnik, p. 137.

12 A. A. Witusik, Sejm elekcyjny Jana Kazimierza, p. 151.

13 A. Przyboś, Michał Korybut Wiśniowiecki 1640-1673, (1984), p. 38.

14 Prawa, konstytucye y przywileie Królestwa Polskiego, Wielkiego Xięstwa Litewskiego y wszystkich prowincyi należących na walnych seymiech koronnych od seymu wiślickiego 
In the context of the topic considered, it is particularly interesting to see the candidacy of the Tsar of Moscow and his sons, because of the religion they professed. One of the most important points raised in support of Moscow was the alleged promise of Aleksey Mikhailovich regarding the conversion to Catholicism of his son, in the event of his election to the throne of the Polish-Lithuanian state. The candidacy aroused anxiety even among foreign envoys, and the author of the statement by the Duke of Transylvania, under the pseudonym $\mathrm{H}$. Zdanowicz, confirmed this claim. Furthermore, Eusebius Brandt (1642-1706), a Prussian agent, claimed at the beginning of 1669 to Frederick William, that the Great Lithuanian Duchy nobility wanted to hand over the crown to the tsar, once he promises to convert to Catholicism. Interesting news about this subject may even have been noted by English diplomats ${ }^{15}$.

Further information about the Moscow candidacy can be found in the diary of the Rector of the Zamoyski Academy, Bazyli Rudomicz (1620-1672). He repeatedly mentions propaganda undertaken by the allies of the Moscow candidature. In his opinion, rumours of Aleksey's adoption of the Catholic faith were widespread, and the Tsar himself had allegedly sought to bring about a total ecclesiastical union ${ }^{16}$. They were also distributing information about the intention to educate Feodor, then only 8 years old, in the Catholic faith. The Roman Church was very reluctant to accept this proposition and did not believe in the hypothetical promises made by Aleksey Mikhailovich, who was supposed to serve mainly as a supporter during the electoral struggle. Furthermore, a majority of noble society did not believe in the promises of the Tsar, and Andrzej Olszowski (1621-1677) wrote directly that the ruler of Moscow would be tempted to take the throne of the Republic, however, exclusively under his conditions, the throne would be hereditary and there would be no change of religion: "There is no hope that a Moscovite would have the least intention of accepting the Roman Catholic faith. He stubbornly persists in schism and he is being tested on the change of religion in vain" (in Polish: "Nie ma

roku pańskiego 1347 aż do ostatniego seymu, (Volumina legum. Przedruk zbioru praw 5, 1860), p. 11; M. Chmielewska, Sejm elekcyjny Michała, pp. 172-173.

15 M. Chmielewska, Sejm elekcyjny Michała, p. 65; Francis Sanderson do N.N., The National Archives, Kew. State Paper Foreign, Poland and Saxony, 88/11, pp. 9-10.

16 B. Rudomicz, Efemeros, czyli Diariusz prywatny pisany w Zamościu w latach 1665-1672, 2: 1656-1664, ed. by W. Froch, M. L. Klementowski, (2002), p. 202. 
żadnej nadziei na to, aby Moskal żywił przynajmniej zamiar przyjęcia wiary rzymsko-katolickiej. Nader uparcie trwa on w schizmie i na próżno bada się go w sprawie zmiany wyznania"). Even the Pac, who were considered supporters of Aleksey Mikhailovich, in reality only supported him on a poll basis and quite quickly abandoned this political option. Finally, the Moscow candidature was not notified and was therefore not considered by the electoral commission ${ }^{17}$.

During the interregnum, after the abdication of Jan Kazimierz, there was also another idea, which assumed that Frederick William, Elector of Brandenburg, could be elected to the throne of the Polish-Lithuanian Commonwealth, even though he was a protestant. These ideas had already appeared, and their creator was the Great Crown Marshal Jerzy Sebastian Lubomirski (1616-1667), who emphasized that "the Polish crown is also worth a mass" (in Polish: "korona polska jest również warta mszy"). Therefore, he referred to the idea of the Brandenburg diplomat, Johann von Hoverbeck (1606-1682), from 1648, who claimed that it was worth even abandoning Calvinism in order to obtain the crown of the Polish-Lithuanian Commonwealth, although some historians believe that this was only courteous behaviour on the part of the deputy. This idea was quite popular in Greater Poland, where its main supporters were Krzysztof Grzymułtowski (1620-1687) and Kazimierz Jan Opaliński (1639-1693) and also the nobility gathered around them. Such actions intensified as a result of the information about the coming abdication of Jan Kazimierz. Even Bogusław Radziwiłł (1620-1669), on behalf of a certain group of Lithuanian senators, suggested to the elector that he should abandon the idea of introducing

17 Censura candidatorium sceptri polonici. Ocena kandydatów do tronu polskiego, ed. by K. Przyboś, A. Perłakowski, (2014), p. 7; M. Chmielewska, Sejm elekcyjny Michała, p. 66; Z. Wójcik, Między traktatemm andruszowskim a wojną turecką. Stosunki polsko-rosyjskie 1667-1672, (1968), pp. 126-127; Z. Wójcik, Pacowie wobec kandydatury rosyjskiej na tron polski w latach 1668-1669 (misja Połkowa na Litwie, 1668), in: Przeglad Historyczny, 60, 1 (1969), pp. 144-145; K. Bobiatyński, Kandydatura Romanowów na tron Rzeczypospolitej podczas elekcji 1669 i 1674 roku. Realna koncepcja, czy też gra polityczna?, in: Prablemy intègracyi i inkarparacyi y̆ razvicci Cèntral'naj i Ushodnâj Ey̆ropy y̆ peryâd rannâga Novaga času, eds. S. F. Sokal, A. M. Ânuškevič (Праблемы інтэграцььі і інкарпарацььі ў развіциці Цэнтральнай $і$ Усходняй Еўропь у перыяд ранняга Новага часу, eds. С. Ф. Сокал, А. М. Янушкевіч), (2010), pp. 349-351; K. Bobiatyński, Michał Kazimierz Pac, wojewoda wileński, hetman wielki litewski, (2008), p. 199; A. Przyboś, Michał Korybut Wiśniowiecki, pp. 41-43. 
Philip Wilhelm of Neuburg to the throne and fight for the crown himself. In this case, even primate Mikołaj Prażmowski (1617-1673) sympathized with the Brandenburg Elector. Nonetheless, the main condition of this election was the conversion of Frederick William to Catholicism. Even the envoy of the Vatican, the Nuncio Geleazzo Marescotti (1627-1726), supported this idea ${ }^{18}$.

After Jan Kazimierz's abdication, Polish-Lithuanian nobility was interested in the faith of other candidates. Rumours were spread about Jan Sobieski's contacts with the English Queen Mother Henrietta Maria (1609-1669). She was to convince the Duke of York, James (1633-1702), the brother of the English king, Charles II (1630-1685), to change his religion to Catholicism and fight for the Polish-Lithuanian crown. He converted to Catholicism in $1670^{19}$.

They also talked about the faith of one of the most important candidates for the Polish throne Charles of Lorraine. Even Andrzej Olszowski praised his virtues, including those associated with faith: "He is a Catholic with a long history. None of the religious innovations of the neighbours have encroached upon or undermined their existence in the true faith" (in Polish: "Jest on katolikiem $\mathrm{z}$ dawien dawna ukształtowanym pobożnością przodków. Żadne nowinki religijne sąsiadów ani nie skaziły, ani nie zachwiały ich trwania przy prawowitej wierze") ${ }^{20}$. He was to be supported by clergy and Jesuits, and was also supported by the Pope ${ }^{21}$.

The importance of the religion of the future ruler is reflected in numerous propagandistic journals from 1669, in which, very often, the candidates for the Polish throne are discussed in terms of their creed. The most popular, Censura candidatorum by Andrzej Olszowski, was mentioned above. In another letter, the anonymous author rejected the candidature

18 A. Kamieński, Kandydatura Hohenzollernów brandenburskich do tronu polskiego od XVI do końca XVIII wieku. Realny cel czy też gra polityczna?, in: Między Zachodem a Wschodem. Etniczne, kulturowe i religijne pograniczna Rzeczypospolitej w XVI-XVIII wieku, eds. K. Mikulski, A. Zielińska-Nowicka, (2006), pp. 31-33; B. Szymczak, Działalność dyplomacji brandenburskiej w okresie bezkrólewia w Rzeczypospolitej w 1648 r., in: Przegląd Historyczny, 89, 1 (1998), p. 26; A. A. Witusik, Sejm elekcyjny Jana Kazimierza w 1648 roku, (Annales Universitatis Marie Curie-Skłodowska, Sectio F, 17, 7, 1962), p. 128.

19 M. Chmielewska, Sejm elekcyjny Michała, p. 68; A. Przyboś, Michał Korybut Wiśniowiecki, p. 43.

${ }^{20}$ Censura candidatorum, p. 57.

${ }^{21}$ M. Chmielewska, Sejm elekcyjny Michała, pp. 80-81. 
of the Elector of Brandenburg, Friderick William, and that of the Tsar, just because of the religion they professed ${ }^{22}$. Interestingly, the former mentioned in 1661, that he was ready to change his religion in order to obtain the Polish crown. Another pamphlet written by Gottfried Wilhelm Leibniz (1646-1716), published under the pseudonym Georgius Ulicovius Lithuanus, emphasized the values of Philip William of Neuburg, and among these, it was mentioned that he was a Catholic. In Censura candidatorum Olszowski stated that le Grand Condé was only a nominal Catholic. For some, the electoral struggle also included the Swedish Queen Christina (1629-1689), who, after her abdication, was converted to Catholicism ${ }^{23}$.

In 1669, however, it was the candidacy of 'the Piast', which proved most popular. Widely promoted by Andrzej Olszowski, he is considered as being one of the chief promoters of the election of Michał Korybut Wiśniowiecki. He was declared king, contrary to the intentions of the magnates, by the nobles gathered at the parliamentary session on $19^{\text {th }} \mathrm{June}^{24}$.

On 10 November, 1673, Michał Korybut Wiśniowieck died. The war with Turkey, in which the Commonwealth was unsuccessful, had led to the loss of the Kamieniec Podolski, the unfavorable peace settlement in Buczacz, and the loss of Podole and parts of the so-called Prawobrzezina Ukraina. The Polish-Lithuanian state became a vassal of the Ottoman Empire and had to pay annual tribute, which the nobles did not want to agree to. This fatal situation was not even changed by the splendid victory of Jan Sobieski at Chocim on the day after the king's death, although it had an impact on electioneering during the following interregnum ${ }^{25}$.

Candidates for the Polish crown were few, and, as in 1669, the Catholic, Charles de Lorraine, was a good prospect for the crown. Candidates also included: Louis de Bourbon, Prince George of Denmark (1653-1708), and Philip William of Neuburg. A new candidate was Charles (1655-1674) from Brandenburg, son of Friderick William the Great Elector, whose

22 Zakład Narodowy im. Ossolińskich we Wrocławiu, ms. 13777/I: Dyskurs polityczny ziemianina polskiego czasom teraźniejszym o kandydatach korony polskiej kogo by z nich obrać i który by najsposobniejszy być mógł do rządów polskich aktykowany w roku pańskim 1669 wszystkiej ojczyźnie do wiadomości podany, p. 8.

23 A. Przyboś, Michał Korybut Wiśniowiecki, pp. 39-43.

24 Ibidem, pp. 57, 62.

25 J. Tazbir, Polskie przedmurze chrześcijańskiej Europy mity a rzeczywistość historyczna, (1987), pp. 76-77. 
candidacy had been widely canvassed when Michal Korybut was still alive. The Protestant denomination of the last mentioned, according to one of his followers, Jan Andrzej Morsztyn (1621-1693), was not a big problem; it was most important for Charles to attend Mass. The Brandenburg elector was not discouraged, even by demands for the return of Drahim, Bytów, and Lembork to the Polish-Lithuanian Commonwealth. The Great Elector was particularly interested in gaining the support of Jan Sobieski for his plans. However, in exchange for his support, Sobieski demanded the conversion of Charles to Catholicism and the incorporation of the Duchy of Prussia to the Polish-Lithuanian Commonwealth. The negotiations were held by Jan Ignacy Bąkowski (1615-1679) and the Brandenburg diplomat, Johann von Hoverbeck. Afterwards, the demands were reduced by resigning from territorial claims. Therefore, the political game focused on the conversion of Charles to Catholicism. Nonetheless, the Brandenburg Secret Council did not agree with this requirement, and the Great Elector had to resign from forcing his son's candidacy ${ }^{26}$.

During the interregnum in 1674 a candidate from Moscow Feodor, the son of Tsar Aleksey Mikhailovich, was considered for election once again. Above all, this idea was supported by representatives of the Pac Family (Michał Kazimierz and Krzysztof Zygmunt), with whom the deputies from Moscow had sympathized throughout the whole interregnum. Naturally, the main demand for the candidacy of Feodor was his conversion to Catholicism. However, the Tsar did not consent to this. Then, a new idea, created by the Moscow court, was that the Tsar himself would be a new candidate for the throne. However, it should be mentioned that the negotiations between the Pac Family and Tsar were only a political game as an element of pressure during the talks with the other contenders for the crown. The election of the Tsar as the ruler of the Polish-Lithuanian Commonwealth was, more likely, doomed to failure ${ }^{27}$.

26 A. Kamieński, Działania dyplomacji brandenburskiej w Polsce podczas elekcji 1674 roku, in: Wieki Stare i Nowe, 8 (13), (2015), pp. 31-35; idem, Polska a Brandenburgia-Prusy w drugiej połowie XVII wieku. Dzieje polityczne, (2002), pp. 91-93, 98; O. Forst de Battaglia, Jan Sobieski król Polski, (1983), pp. 64-66.

27 K. Bobiatyński, W walce o hegemonię. Rywalizacja polityczna $w$ Wielkim Księstwie Litewskim w latach 1667-1674, (2016), pp. 259-262; idem, Kandydatura Romanowów na tron, pp. 353-356; B. N. Florâ, Rossiâ i èlekciâ v Reči Pospolitoj 1674 goda, in: Srednie veka 
Sobieski was initially ignored in the electoral process and supported the French candidate. When, however, he decided to start fighting for the throne of the Commonwealth, one of the main points, which was raised at that time, were his victories, especially those from Chocim, where, according to modern opinion, he had defeated the dissidents and saved Christian Europe. The Emperor Leopold I (1640-1705) himself, referring to Sobieski's success of November 1673, wrote to the Pope that Poland is the antemurale christianitatis. Some described Jan III as "a man sent by God"28.

After the death of Jan III Sobieski, the Prince of Conti, François Louis de Bourbon (1664-1709) and Jakub Sobieski (1667-1737), were among the main candidates for the throne. In 1697 the candidacy of the Elector of Saxony, Fryderyk August I for the throne of the Commonwealth, was submitted to Primate Michał Radziejowski (1645-1705) by Jakub Henryk Fleming (1667-1728). However, the cleric declared that the Protestant's application to contend for the throne was impossible due to the laws of the Polish-Lithuanian state. Initially, the Elector was not very popular within nobility. The biggest complaints involved the absence of conversion confirmation by Fryderyk August I, whose credentials the imperial ambassador and papal nuncio did not want to expose. The Elector of Saxony changed his faith in secret on 2 June, 1697, in the castle above the town of Baden belonging to the Habsburgs. This conversion was made by his cousin, Christian August von Sachsen-Zeitz (1666-1725), who was not known in Poland, and therefore a confirmation from known persons was required ${ }^{29}$. An important role in electing Fryderyk August I was played by the Emperor's ambassador, Johann Philipp Lamberg (1652-1712) (a specialist in knowledge regarding the Roman Catholic faith), who, together with the Pope's nuncio, examined him in the Catholic faith ${ }^{30}$.

The Emissaries of King Louis XIV (1638-1715) tried to win the most important magnates of the Republic for their candidacy, including the Lithua-

(Ъ. Н. Флоря, Россия и элекиия в Речи Посполитой 1674 года, in: Средние века), 76, 1-2 (2015), p. 275-279.

28 Z. Wójcik, Jan III Sobieski, pp. 217-220; J. Tazbir, Polskie przedmurze chrześcijaństwa, p. 77.

29 J. Staszewski, August II Mocny, (1998), pp. 54, 59.

${ }^{30}$ M. Kondrádová (Hrušková), Elekcje królów polskich w II połowie XVII wieku oczyma dyplomatów cesarskich, in: Wokół wolnych elekcji w państwie polsko-litewskim XVI-XVIII wieku, eds. M. Markiewicz, D. Rolnik, F. Wolański, (2016), p. 305. 
nians. Furthermore, the leaders of the Grand Duchy, which included the Sapieha brothers, the Lithuanian Treasurer Benedykt Paweł (1655-1707/1708), and the Great Hetman, Kazimierz Jan (1637-1720), as well as the attitude of Dominik Mikołaj Radziwiłł (1643-1697), were taken into consideration. In one of his letters, we find information about the future king and his obligations. Lithuanians listed four conditions, the most important of which was that he must be a Catholic. This brief information perfectly illustrates the moods of the magnates of the Commonwealth, including the Lithuanian one, which did not want an Orthodox believer from Moscow on the throne. To a degree, this proves a change in the attitude towards religion of the inhabitants of the Grand Duchy, who, in the late seventeenth century, did not want to have a dissident as king ${ }^{31}$. Furthermore, French diplomats pointed out that the citizens of the Commonwealth would only take a Catholic as a king in their correspondence and reports ${ }^{32}$.

After Jakub Sobieski had withdrawn from the electoral battle, the French candidate, Duke Conti, enjoyed the greatest support. The interest of the Saxon Elector, Frederick August I, was growing greater and greater, especially after scattering a copy of the Nuncio's certificate on the electoral field, stating that he had converted to Catholicism. This was a well planned political action, which directly influenced the mood of the nobles gathered in Warsaw. The representatives of the Saxon Elector, the Brandenburg diplomats, the Venetian ambassador and members of the anti-French factions had met the night before the announcement of the electoral results. They had all decided to cast their vote for Fryderyk August I, which was determined primarily by the good of the Holy League, which would have suffered in the case of a vote for Conti. Despite the attempted bargaining, there was a division in the electoral college. On 27 June, Primate Michał Radziejowski, together with the Kuyavian bishop Stanisław Kazimierz Dąmbski (1638-1700) and the Elector of Saxony, Fryderyk August I, proclaimed Duke Conti the Polish-Lithuanian King. The elector of Saxony came

31 M. Sawicki, Magnaci litewscy w świetle francuskojęzycznej korespondencji z lat 90 XVII wieku w archiwum drezdeńskim, in: Epistolografia w dawnej Rzeczypospolitej, 6: stulecia XVI-XIX, Perspektywa historyczna i językowa, eds. P. Borek, M. Olma, (2013), p. 164.

32 Archives Ministère des Affaires Étrangères et du Développement International République Française à Paris, Correspondance Politique, Pologne, vol. 40, p. 28v: A Lublin le 21 mars atrois heures apres minuict. 
to the Commonwealth first, so that he could more quickly and efficiently attract new supporters, which helped him maintain the throne ${ }^{33}$.

Religion was used in many dimensions and aspects, and the candidates for the throne, their supporters, and foreign diplomats were well aware of its importance. By analyzing above issues, we should remember about processes which have progressed in the $17^{\text {th }}$ century Europe and were related to confessionalisation and the transformation of the state system. Due to these, the dependencies between state and religion were constantly changing, which certainly had its connotation also during the election in the Commonwealth ${ }^{34}$. The above brief analysis, which draws attention to the most important aspects of the proposed problem, is only a starting point for further consideration. On the other hand, it is clear from the above that appropriate steps taken by the pretender to the Polish throne in religious matters may have influenced, or influenced to a great extent, the outcome of the election. The religion of the future monarch had been of importance since the first interregnum, and, for the voters, it was also important for him to tolerate differences in faith. For this reason, dissenters appreciated the rule of Władysław IV, who proved less rigorous in this regard than his father, Zygmunt III. They appreciated the actions of the younger Vasa, even from the time of interregnum in 1632, when he tried to bring about a settlement between the warring parties, Catholics, and other religions. Religious tolerance also played an important role during the next interregnum, when Janusz Radziwiłł tried to plant a Protestant protector, George Rákóczi and his son Zygmunt, on the throne of the Commonwealth. The dissidents decided to support Jan Kazimierz Vasa only after he accepted the conditions for their functioning in the state. The religion professed by the candidates to the throne in 1669 was especially important, when, in every propaganda letter, it was stated that the future monarch should be a Catholic and that the claimants of another religion were explicitly rejected. In an interesting way, the possibility of conversion to Catholicism was tried by the Moscow Tsar, but, for various reasons, his plans failed. After the death of King Michał Korybut Wiśniowiecki, the

33 J. Staszewski, August II Mocny, p. 60.

${ }^{34}$ H. Schilling, Jedność i różnorodność we wczesnej epoce nowożytnej: religia-społeczeństwo-państwo, translated by J. Górny, K. Kowalewski, (2010), p. 209; H. Schilling, Konfesjonalizacja. Kościół i państwo w Europie doby przednowoczesnej, translated by J. Kałążny, (2010), pp. 311-316. 
election of Jan III Sobieski was directly influenced by the events of the defeat of the Turks at Chocim. August II Mocny was the last elected ruler of the Commonwealth in the seventeenth century, a Protestant from birth, who manipulated the mood of the Sejm at a crucial moment and confirmed his conversion to Catholicism at the decisive point. Of course, it is not fair to say that religious issues have had a decisive impact on the outcome of electoral struggles. The issue of religion, which was extremely important for noble society and even magnates, was certainly one of the most important aspects that influenced the choice of a particular candidate for the throne of the former Commonwealth.

Translated by

Daniel Pawleta

\section{ROLA I WYKORZYSTANIE RELIGII \\ W POLITYCE KANDYDATÓW DO TRONU POLSKIEGO \\ W XVII WIEKU}

STRESZCZENIE

Podczas bezkrólewia i w okresie wolnej elekcji dokonywano wyboru przyszłego króla Rzeczypospolitej. Pretendenci do tronu próbowali wielu sposobów, aby uzyskać poparcie szlachty. Niewątpliwie jednym z najważniejszych tematów $\mathrm{w}$ rokowaniach $\mathrm{z}$ kandydatami na tron był stosunek do innych wyznań i deklarowana tolerancja (lub nietolerancja) wobec do dysydentów. Ich stosunek do religii oraz składane w tym zakresie obietnice były więc niekiedy istotnym elementem w rozgrywkach politycznych.

\section{DiE ROLlE UND NUTZUNG DER RELIGION \\ IN DER POLITIK DER KANDIDATEN FÜR DEN POLNISCHEN THRON IM 17. JAHRHUNDERT}

ZUSAMMENFASSUNG

Während des Interregnums, also zwischen dem Tod des alten Königs und dem Zeitpunkt der Neuwahl, wurde der zukünftige König der Rzeczpospolita in einem hochspannenden politischen Prozess bestimmt. Die Thronprätendenten haben viele Möglichkeiten versucht, um die Unterstützung des Adels zu gewinnen. Zweifellos war eines der wichtigsten Themen bei den Verhandlungen mit den Kandidaten für den Thron deren Verhältnis zu anderen Religionen und die erklärte Toleranz (oder Intoleranz) gegenüber den Dissidenten. Ihre Einstellung 
zur Religion sowie die diesbezüglichen Versprechen waren manchmal ein entscheidendes Element in der politischen Auseinandersetzung.

Übersetzt von

Renata Skowrońska

\section{THE ROLE AND USE OF RELIGION \\ IN THE POLITICS OF CANDIDATES TO THE POLISH THRONE \\ IN THE $17^{\text {th }}$ CENTURY}

SUMMARY

During the interregnum and in the period of royal free elections the choice of the future king of the Polish-Lithuanian Commonwealth took place. Pretenders to the throne used various methods to win the support of noblemen. Undoubtedly, one of the most important issues discussed during the negotiations with them was their attitude towards other denominations and their tolerance or intolerance towards dissidents. Their attitude towards religion and promise made in this respect constituted a fundamental element of political contests.

Translated by Agnieszka Chabros

\section{SŁOWA KLUCZOWE / SCHLAGWORTE / KEYWORDS}

- Rzeczpospolita; XVII wiek; szlachta; wolna elekcja; tolerancja religijna

- Polen-Litauen; 17. Jahrhundert; Adel; freie Wahl; religiöse Toleranz

- Polish-Lithuanian Commonwealth; XVII century; nobility; free election; religious tolerance

\section{BIBLIOGRAFIA / BIBLIOGRAFIE / BIBLIOGRAPHY}

\section{ŹRÓDłA ARCHIWALNE / ARCHIVALISCHE QUELLEN / ARCHIVAL SOURCES}

Archives Ministère des Affaires Étrangères et du Développement International République Française à Paris, Correspondance Politique, Pologne, vol. 40.

The National Archives, Kew. State Paper Foreign, Poland and Saxony, 88/11.

Zakład Narodowy im. Ossolińskich we Wrocławiu, ms. 13777/I: Dyskurs polityczny ziemianina polskiego czasom teraźniejszym o kandydatach korony polskiej kogo by $z$ nich obrać $i$ który by najsposobniejszy być mógł do rządów polskich aktykowany w roku pańskim 1669 wszystkiej ojczyźnie do wiadomości podany. 


\section{ŹródŁA DRUKOWANE / GEDRUCKTE QUELLEN / PRINTED SOURCES}

Censura candidatorium sceptri polonici. Ocena kandydatów do tronu polskiego, ed. by K. Przyboś, A. Perłakowski, (2014).

Prawa, konstytucye y przywileie Królestwa Polskiego, Wielkiego Xięstwa Litewskiego y wszystkich prowincyi należacych na walnych seymiech koronnych od seymu wiślickiego roku pańskiego 1347 aż do ostatniego seymu, (Volumina legum. Przedruk zbioru praw 5, 1860).

Rudomicz B., Efemeros, czyli Diariusz prywatny pisany w Zamościu w latach 1665-1672, 2: 1656-1664, devepoled by W. Froch, M. L. Klementowski, (2002).

"Spisek orleański" w latach 1626-1628, eds. U. Augustyniak, W. Sokołowski, (1990).

\section{LITERATURA / LITERATUR / LITERATURE}

Anusik Z., Gustaw II Adolf, (1996).

Bobiatyński K., Kandydatura Romanowów na tron Rzeczypospolitej podczas elekcji 1669 i 1674 roku. Realna koncepcja, czy też gra polityczna?, in: Prablemy intègracyi $i$ inkarparacyi y̆ razvicci Cèntralnaj i Ushodnâj Ey̆ropy y̆ peryâd rannâga Novaga času, eds. S. F. Sokal, A. M. Ânuškevič (Праблемы інтэграцыь і інкарпарацььі у развіциі Цэнтральнай $і$ Усходняй Еўропы ў перыяд ранняга Новага часу, eds. С. Ф. Сокал, А. М. Янушкевіч), (2010).

Bobiatyński K., Michał Kazimierz Pac, wojewoda wileński, hetman wielki litewski, (2008).

Bobiatyński K., W walce o hegemonię. Rywalizacja polityczna w Wielkim Księstwie Litewskim w latach 1667-1674, (2016).

Czapliński W., Na dworze króla Władysława IV, (1959).

Czapliński W., Na dworze Władysława IV, (1959).

Dorobisz J., Biskup i książę. Jakub Zadzik i Krzysztof II Radziwiłł w elicie władzy pierwszych Wazów, in: Patron i dwór. Magnateria Rzeczypospolitej w XVI-XVIII wieku, eds. E. Dubas-Urwanowicz, J. Urwanowicz, (2006).

Dzięgielewski J., O tolerancję dla zdominowanych. Polityka wyznaniowa Rzeczypospolitej w latach panowania Władysława IV, (1986).

Florâ B. N., Rossiâ i èlekciâ v Reči Pospolitoj 1674 goda, in: Srednie veka (Флоря Ђ. Н., Россия иэлекиия в Речи Посполитой 1674 года, in: Средние века), 76, 1-2 (2015).

Forst de Battaglia O., Jan Sobieski król Polski, (1983).

Kaczorowski W., Sejmy konwokacyjny i elekcyjny w okresie bezkrólewia 1632 r., (1986).

Kamieński A., Działania dyplomacji brandenburskiej w Polsce podczas elekcji 1674 roku, in: Wieki Stare i Nowe, 8 (13) (2015).

Kamieński A., Kandydatura Hohenzollernów brandenburskich do tronu polskiego od XVI do końca XVIII wieku. Realny cel czy też gra polityczna?, in: Między Zachodem a Wschodem. Etniczne, kulturowe i religijne pograniczna Rzeczypospolitej w XVI-XVIII wieku, eds. K. Mikulski, A. Zielińska-Nowicka, (2006).

Kamieński A., Polska a Brandenburgia-Prusy w drugiej połowie XVII wieku. Dzieje polityczne, (2002).

Kondrádová (Hrušková) M., Elekcje królów polskich w II połowie XVII wieku oczyma dyplomatów cesarskich, in: Wokół wolnych elekcji w państwie polsko-litewskim XVI-XVIII wieku, eds. M. Markiewicz, D. Rolnik, F. Wolański, (2016). 
Ochmann-Staniszewska S., Dynastia Wazów w Polsce, (2006).

Przyboś A., Michał Korybut Wiśniowiecki 1640-1673, (1984).

Rachuba A., Sapieha Kazimierz Leon, in: Polski Słownik Biograficzny, 35, 1 (1994).

Sawicki M., Magnaci litewscy w świetle francuskojęzycznej korespondencji z lat 90 XVII wieku w archiwum drezdeńskim, in: Epistolografia w dawnej Rzeczypospolitej, 6: stulecia XVI-XIX, Perspektywa historyczna i językowa, eds. P. Borek, M. Olma, (2013).

Sawicki M., Stronnictwo dworskie w Wielkim Księstwie Litewskim w latach 1648-1655, (2010).

Schilling H., Confessionalization: Historical and Scholarly Perspectives of a Comparative and Interdisciplinary Paradigm, in: Confessionalization in Europe, 1555-1700: Essays in Honor and Memory of Bodo Nischan, ed. J. M. Headley, H. J. Hillerbrand, A. J. Papalas, (2004).

Schilling H., Jedność i różnorodność we wczesnej epoce nowożytnej: religia-społeczeństwopaństwo, translated by J. Górny, K. Kowalewski, (2010).

Schilling H., Konfesjonalizacja. Kościół i państwo w Europie doby przednowoczesnej, translated by J. Kałążny, (2010).

Staszewski J., August II Mocny, (1998).

Szelągowski A., Układy królewicza Władysława i dysydentów z Gustawem Adolfem w r. 1632, in: Kwartalnik Historyczny, 13 (1899).

Śliwiński A., Król Władysław IV, (1924).

Szymczak B., Działalność dyplomacji brandenburskiej w okresie bezkrólewia w Rzeczypospolitej w 1648 r., in: Przeglad Historyczny, 89, 1 (1998).

Tazbir J., Polskie przedmurze chrześcijańskiej Europy mity a rzeczywistość historyczna, (1987).

Tomkiewicz W., Jeremi Wiśniowiecki (1612-1651), (1933).

Wasilewski T., Ostatni Waza na polskim tronie, (1984).

Wisner H., Władysław IV Waza, (2002).

Wisner H., Zygmunt III Waza, (2006).

Witusik A. A., Sejm elekcyjny Jana Kazimierza w 1648 roku, (Annales Universitatis Marie Curie-Skłodowska, Section F, 17, 7, 1962).

Wójcik Z., Jan Kazimierz Waza, (1997).

Wójcik Z., Między traktatemm andruszowskim a wojną turecką. Stosunki polsko-rosyjskie 1667-1672, (1968).

Wójcik Z., Pacowie wobec kandydatury rosyjskiej na tron polski w latach 1668-1669 (misja Połkowa na Litwie, 1668), in: Przeglad Historyczny, 60, 1 (1969). 